\title{
Investigation of the Experiences of Classroom Teacher Candidates in the Reconstruction of Gender Role: A Case Study in Turkey
}

\author{
Fatmanur Özen \\ Correspondence: Fatmanur Özen, Faculty of Education, Giresun University, Giresun, Turkey. \\ Received: April 13, 2018 \\ doi:10.11114/jets.v6i8.3211

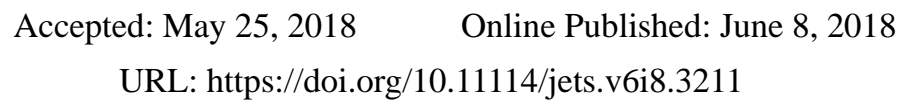

\begin{abstract}
This research, examining the perception of classroom teacher candidates about the gender equality through the personal experiences of the teacher candidates, is a qualitative study. The phenomenological pattern was adopted. Data were collected in two stages: The participants were asked to provide written responses to the open-ended questions for clarifying which concepts are used for explaining the gender equality, which factors cause the gender inequality and how the equality will be ensured. Next, focus group discussion was carried to find the situations that the classroom teacher candidates encountered in their learning process. The results reveal that the role of men and women, generated by the cultures of different societies but the individuals should have equal rights and opportunities and every kind of discrimination about sex should be prevented. The causes of inequality: Socialization, social roles. The factors causes the inequality are the religious beliefs, prejudices, patriarchy. For the equality, it is necessary to raise awareness, the roles in the family should be re-arranged and women employment should be supported. The results of the focus group discussion announced that biological gender was effective in choosing the profession: Men were more successful in professions working with numbers and producing some concrete products, while the women should be employed in professions that would guarantee the emotional and physical security. Women are successful in the management because of their maternal roles and they attach a great importance to details and organization. However, the governance, in other words, the power is the men's specialty.
\end{abstract}

Keywords: gender, gender equality, the perception of gender roles, class teacher candidate

\section{Introduction}

Gender signifies the behavioral, cultural, or psychological traits typically associated with one sex (Merriam Webster). According to the World Health Organization, gender refers to the socially constructed characteristics of women and men. These characteristics regulate as norms, roles, and relationships of and between groups of women and men. (http://www.who.int/gender-equity-rights/understanding/gender-definition/en/). The American Psychological Association (2012) provides the following definitions for sex and gender that are generally confused: The sex refers to a person's biological status and is typically categorized as male, female, or intersex. Gender refers to the attitudes, feelings, and behaviors that a given culture associates with a person's biological sex. Behavior that is compatible with cultural expectations referred to as gender-normative. Thus, while sex is the genetic, physiological, and biological characteristics of an individual as a woman or a man, gender refers to roles and responsibilities that are "socially given to women and men in different cultures, at different times and in different geographies ..." (Mason, 1997, p: 158). In other words, each social system prescribes specific behaviors for men and women and prescribes a division of labor and responsibilities between men and women (Istanbul Psychiatric Institute).

The sociology of gender examines how our social understanding affects our perception of masculinity (which behaviors are suitable for men) and femininity (which behaviors are suitable for women) (Brickell, 2006). Masculinity/femininity dimension of Hofstede (1986) refers to the extent that determines the role of men and women in the society:

In the masculine cultures, men are supposed to be assertive, ambitious, competitive, tough and focused on material success. On the other hand, masculine cultures do not expect from women to generate income, they are supposed to take care of children and elder people. On the other hand, emotional gender roles overlap in the feminine cultures. Particularly, the men are not supposed to be assertive or competitive. They are more concerned with the quality of life rather than financial gains, and they should be respectful no matter what. 
Thus, masculine cultures are more individualistic while feminine cultures are more collectivists since they emphasize on the personal relationships. While the dominant values in the masculine cultures are acquiring and achieving, the dominant values in feminine cultures are the care for each other and quality of life. Although the differentiation in roles is limited in the feminine cultures, the differentiation is more critical in masculine cultures. In masculine cultures, a few houseworks are done by the men (Mooij \& Hofstede, 2010). Thus, all societies are structured according to the type of culture they prefer, sharing the tasks and responsibilities in the common area, adopting norms, ethical values, rules, and generating roles and behaviors that the societies consider appropriate for the gender.

Three primary approaches of sociology, namely, Socialization Approach/Structural-Functional Approach (Materialist-Marxist-Feminist Approach, Radical Approach/Feminism), Symbolic Interaction Approach, Social Conflict (Deconstruction) Approach assert different opinions about the importance of gender within the social organization (Çaban, 2005). The social approach explains gender in terms of positivist functional theories. The nuclear family model developed by Parsons (1955) explains the gender roles according to the American perspective of the Industrial Era (quoting from Shepherd, 2008). This perspective considers the family as the most equipped unit to fulfill the needs of the community, and the roles are specialized in the family. The roles are shared according to the reproductive characteristics of the human body, and this division determines our personal experience as well as our social roles. For this reason, when the fertile woman assumes a loving and emotional role in the family, the man works out to make a living (Oakley, 1989, quoting from Reid, 2008; Tanrı̈̈ver \& Danac1-Yüce, 2007).

The Marxist theory explains gender equality through power relations as well as it explains in terms of the division of labor and division relationships. According to the theory, women's unpaid labor within the household supports the interests of both the male of the household and of the capitalist employer, who escapes from the cost of reproduction. Women provide unpaid labor, while men take their share from the suppression and exploitation of women (Aydemir, 2013). In the Social Conflict Approach, Engels describes gender as the power of one sex over the other sex (Brown, 2014). According to the Symbolic Interaction Approach, since the society defines men (and what is defined as masculine) as more valuable than the woman (and what is defined as feminine), practically every social interaction is gendered. To that extent that women and men interact in distinctive and unequal forms. Symbolic interaction suggests that the individual creates social reality in which the individual experiences gender as part of his/her personal performance and interaction. Gender can help in deciding how we will behave, but it exceeds our individual control and "grants some powers to some people on others". Thus, daily patterns of social interaction reflect the gender stratification of our society, and daily interactions cause the "intensification of the inequality" (Macionis, 2012, pp: 333-346).

\subsection{Gender and Education}

Education, which is one of the most significant prerequisites of the modern society, is the exclusive condition of a productive and quality life and for ensuring that the person behaves according to the society's expectations (Özen, 2015). Since the world is rapidly changing and developing, the needs for social transformation and change are increased. Hence, the adaptation and direction of the societies, after following these developments and changes, constitute one of the significant objectives of the societies in the future. The sole strategy for reaching these objectives is definitely the education. Thus, it is necessary to enhance the quality and effectiveness of the education and to plan the education for including all segments of the society (UNICEF \& UNESCO, 2013).

Even in the 21st century, the ignorance is the main problem of many countries. While literacy constitutes still a powerful social value, the right to education is one of the fundamental human rights. Today, national and supranational efforts are made so that everyone in the world uses the right to education: the education is mentioned as a right of everybody in the United National Universal Declaration of Human Rights (UNICEF, 1948). The States adopt this principle as making the primary education compulsory for everyone and also, the States should make effort for providing the access to the education for everybody. This proves the supra-national value that is attached to the education. In 1960, UNESCO adopted the Convention on the Elimination of All Forms of Discrimination in Education, and the Contracting Parties committed that they would "promote equality of opportunity in education while guaranteeing the right to compulsory and free education". The UN Economic, Social and Cultural Rights Convention (1966/1976) declares that the States Parties to the present Covenant undertake to guarantee that the rights enunciated in the present Covenant will be "exercised without discrimination of any kind as to race, colour, sex, language, religion, political or other opinion and all the individuals participate to the society in the efficient way..."(United Nations Human Rights Office). Thus, the UN has stated that different categories in the society may have different needs, and education needs to solve the disputes and conflicts of interests. Hence, it is necessary to adopt the education as a way to ensure the global reconciliation and peace. Among the contracts of the UN: Convention of Elimination of all forms of Discrimination against Women= (CEDAW 1979/1981, the approval of Turkey 1985) and the Education For All Declaration (EFA, 1990) within the signature opened Convention of Rights of Child (the approval of Turkey, 1995), are international conventions that legally strengthen the prevention of gender inequality, particularly in education. 
The right to education was included under the "Economic and Social Rights" heading of CEDAW that Turkey put into force in 1986. State Parties shall take appropriate measures for ensuring the women the equal right with men including, "the same conditions for career and vocational guidance for the achievement in diplomas in educational establishments in rural as well as in urban areas " (article a), "the access to the same curricula, the same examinations, teaching staff with qualifications of the same standard. "(article b)," the elimination of any stereotyped concept of the roles of men and women at all levels and in all forms of education...the coeducation" (article c), "the same opportunities to benefit from scholarships and other study grants." (article d), "the reduction of female student drop-out rates.." (article f), "the same opportunities to participate actively in sports and physical education..." (article g) (https://www.tbmm.gov.tr/komisyon/kefe/docs/cedaw.pdf). Hence the State Parties commit to ensuring the access of women to the educational environments but also the application of curricula that would overcome the stereotyped concept of the roles and women.

Several measures have been taken since the 1960s to ensure gender equality at the global, regional and national level and the women's position as both the contributors and beneficiaries to the society. Countries commenced signing documents to determine policies, establish sub-systems that evaluate their own processes in the context of gender equality, determine strategies, and even commit to international conventions. At the 36th session of UNESCO's general meeting held in 2011, the large majority of both developed and developing country representatives confirmed that the key element of education equality, gender equality, right to education is the "teachers" (UNESCO, 2015). Thus, the Organization emphasized the strategic significance of the teachers as guides, role models in the classes for ensuring an equitable division between the sexes. Since it is known that the perception of gender equality of the teachers affect the teachers' attitudes towards girls and boys in their class (Bigler, Hayes \& Hamilton, 2013; Buell, Hallam, Gamel-McCormick \& Scheer, 1999) and that teachers' stereotypes and perception of gender affect the organization of the teaching environment (Akbaba-Altun \& Apaydın, 2013; Aslan, 2015; Caldarella, Shatzer, Richardson, Shen, Zhang \& Zhang, 2009; Chapman, 2002; Chronaki, 2012; Duffy, Warren \&Walsh, 2001; Kleinfeld, 1998; Kokkinos, Panayiotou \& Davazoglou, 2004; Sadker; 2002; Sadker \& Sadker, 1994; Saltzman, 1994; Sayılan, 2012; Shepardson \& Pizzini, 1992; Sommers, 2000; Tan, Ecevit \& Üşür, 2000), it was deemed necessary to examine the experiences of teacher candidates' gender equality. For this purpose, in this research, we strove to define the experiences of the candidate teachers about the gender equality and we tried to predict their future behaviors in the class.

\section{Method}

This is a qualitative research. Since it is known that the human actions emerge as a result of the interaction between the previous trainings, experiences, current interests and objectives and goals (Hatch \& Wisniewski, 1995, quoting from Carignan, Sanders \& Pourdavood, 2005), the phenomenological model was used for describing the teacher candidates' perception on the gender equality (the research process followed based on the design is summarized in Figure 1). This model is used to focus on phenomena that we are aware of but do not have a comprehensive understanding. The data obtained are described for revealing the meanings and experiences (Yıldırım \& Şimşek, 2006). For this model, the data are collected in two stages. In the first phase, in the fall semester of 2015, a group of classroom teacher candidates $(\mathrm{N}=119)$, studying in the 1st Grade of Classroom Teaching in Primary School, in Giresun University Faculty of Education, was asked to respond following questions via a semi-structured questionnaire: "The definition of gender equality", "The situations where there is a gender inequality", "The factors causing gender inequality", and "What can be done to ensure the gender equality". The data obtained at this stage of the research was combined with the literature and a descriptive analysis has been conducted based on the themes included in the literature.
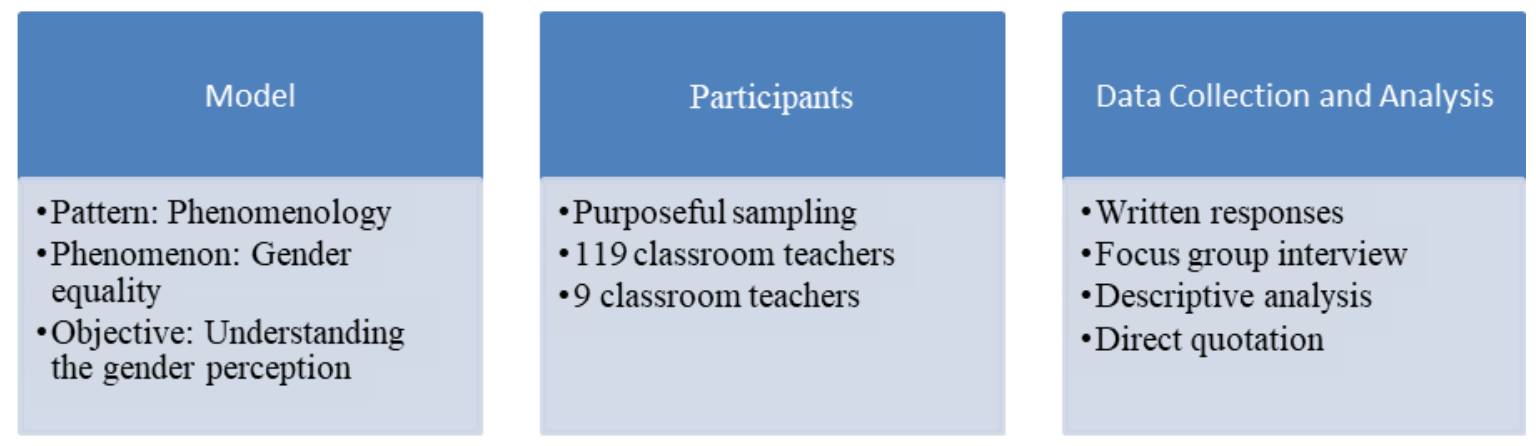

Figure 1. The research process

Descriptive analysis is a research approach that "summarizes and interprets" data according to more "pre-determined themes" (Yıldırım \& Şimşek, 2006, pp: 227, 224). Hence, it provides the researcher to quantify the written expressions, obtained at the end of qualitative studies (Dawson, 2009, p: 122). In the second phase of the study, an in-depth 
interview was conducted with focus group discussion $(\mathrm{N}=9)$ technique with the volunteer students and we strove to describe how the volunteer teacher candidates would display their perception of gender to the classroom environment. In recent years, the focus group discussion technique often used to collect data in action research, has been used to examine the effects of group dynamics, to acquire in-depth information and to generate ideas (Bowling, 2002; quoting from Çokluk, Y1lmaz \& Oğuz, 2011). The data obtained from the interviews are presented through direct quotations. Thus, it was tried to understand whatever the teacher candidates, who participated in the research implicitly learned about gender equality in their prior learning stages, and at the same time, it was tried to predict how the teaching environment of these teachers would be affected by the previous experiences of the teacher candidates.

\subsection{Research Group}

Within the scope of the research, a group of students gave $(\mathrm{N}=119)$ responses in writing while the other group provided verbal responses $(\mathrm{N}=9)$. The study has been conducted by collecting the data from the teacher candidates, who study at the 1st Grade of Classroom Teaching in Primary School, in Giresun University Faculty of Education in the 2015-2016 academic year. While 91 student candidates are female (76,5\%), 28 students are male $(23,5 \%)$. Only 75 of these students agreed to share personal information. Among the teacher candidates, who accepted to share the personal information, the average age of students is 19,4. It is understood that the students had on average three siblings. It is revealed that they spent most of their lives in Giresun (11 students), Trabzon (nine students), Istanbul (five students), Ordu (four students) and the other cities (there are participants from Konya, Düzce, Aksaray, Balıkesir, Iğdır, Kayseri, Rize, Mersin, Aydin, Adana, Erzurum). Among the teacher candidates accepting to share the personal information, all of their fathers have finished at least the primary school (100\%), the mothers of nine candidates (12\%) didn't graduate from any school and probably they are illiterate. Among the teacher candidates, the mothers of two candidates only have graduated from a higher level of school $(2,7 \%)$ while the fathers of the remaining candidates have graduated from a higher level of school (97\%) (while the mother graduated from primary school, the father graduated from secondary school, etc.). Nine teacher candidates, who continue to study classroom teaching participated in the focus group discussions. While three of them are male, siz of them are female. Three of the participants are studying in the fourth grade and the average age is 23 . On the other hand, the remaining participants continue their education in the second grade and the average age is 19,8 . Six of the participants participating in the research had previously taken the Gender Equality Lesson; three of the participants didn't take any courses or attend any seminars, lectures etc. on gender equality.

\subsection{Data Collection and Data Analysis}

The research data was collected in two stages. In the first stage, the participants were asked to respond following questions via a semi-structured questionnaire; "The definition of gender equality", "The situations where there is a gender inequality", "The factors causing gender inequality" and "What can be done to ensure the gender equality" . Two contemplators categorized the date in the light of the themes, collected from the literature. The coefficient rate between two encoders was evaluated by Holst's Method. The coefficient rate is the ratio of the number of coefficient between two encoders to the sum of the number of units encoded. [Coefficient Rate $=$ Number of coefficients between two encoders/Total Number of Units Encoded by A and B Encoders; PA0 $=2 A /(n A+n B)]$ and this number should be between 0 and 1 for the reliability (Neuendorf, 2002, p: 108). According to the calculations, the coefficient rate between the two encoders was found to be $(2061 /(2142)=.96)$ for the definition of gender equality, while it is $(394 /(476)=.83)$ for the situations where there is a gender inequality, it is $(486 /(595)=.82)$ for the factors causing gender inequality, and it is $(2169 / 2380=.91)$ for the things that needs to be done for ensuring the gender equality. All of the values are between zero and one, thus ensuring a coefficient between the encoders.

In the second phase of the study, a focus group discussion was conducted with a group of participants $(\mathrm{N}=9)$. In this context, the participants were asked to answer 11 questions to analyze their previous school experiences and some questions are added during the interview. The interview was taken on the camera after receiving the permission of the participants and a 48-minute interview recording was created in this context. The interview records were written in 18 pages. Direct quotations from the obtained text are included in the findings. Since the participants didn't agree to use their initials on quotations, we only used the first letters of their names.

\section{Findings}

When the definitions of gender equality in the literature are taken into consideration, after revealing the genetic, biological and physical attributes of the individual and the variations between them, it is noted that the gender equality is defined as the roles and responsibilities defined by the cultural characteristics of the society, in which the individual lives. Gender equality, on the other hand, represents equality: equity in the distribution of the role and responsibility between women and men. In this context, the data obtained from candidate teachers participated in the research were categorized as "biological sex, gender and gender equality" and presented in Table 1. 
Table 1. Definitions of gender equality

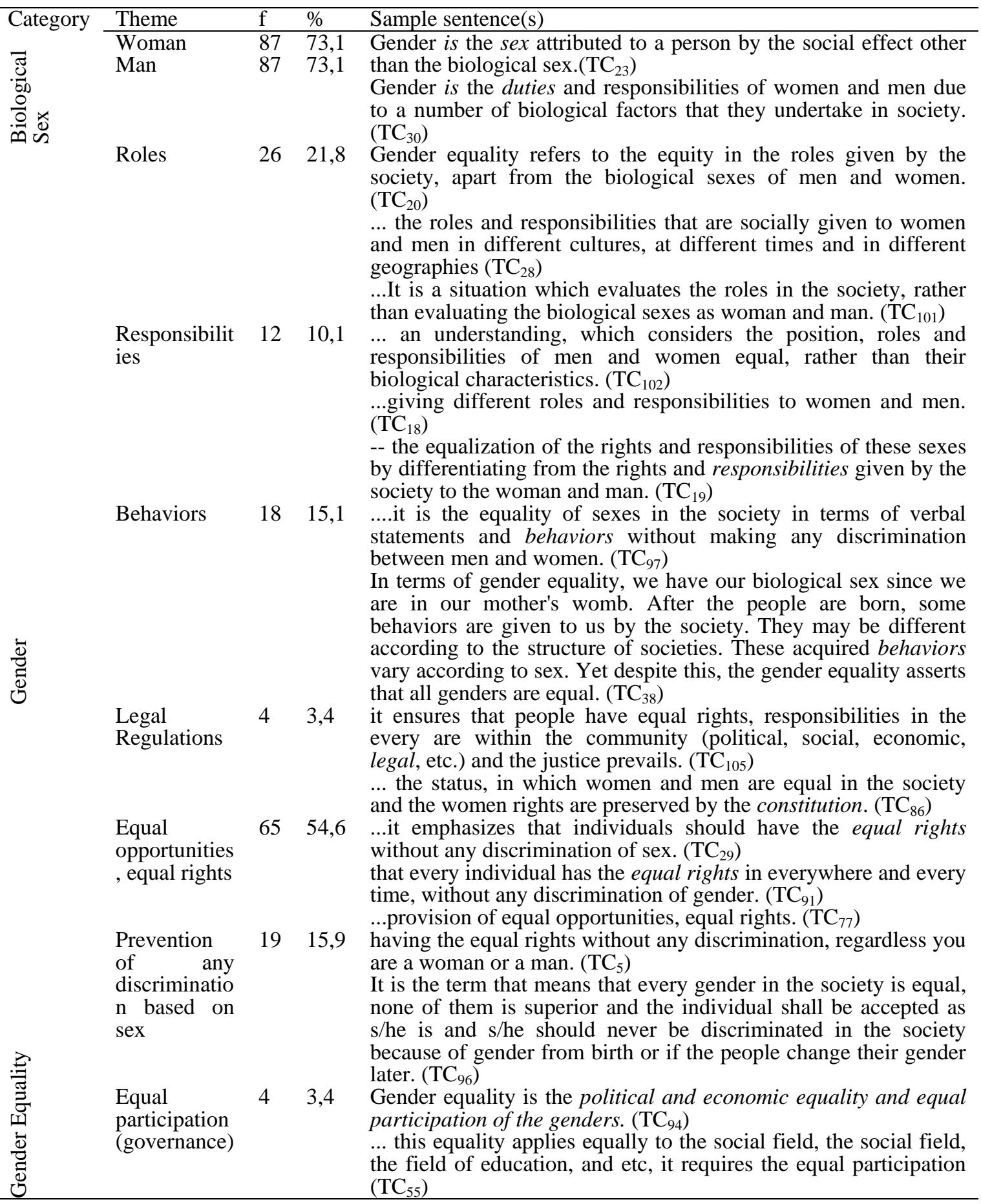

The results obtained by conducting a descriptive analysis of the data of 119 teacher candidates revealed that the teacher candidates described the gender equality in terms of two biological sexes, male and female, and frequently expressed the significance of social roles, behaviors, and responsibilities when describing gender. According to the teacher candidates ""Gender is given socially to people, regardless of the biological gender.., " $\left(\mathrm{TC}_{23}\right)$, experienced "..varying in different geographies and in different times ..." $\left(\mathrm{TC}_{28}\right)$, “... roles given socially...” $\left(\mathrm{TC}_{20,28,101}\right)$, changing according to sex and socially earned "...behaviors" $\left(\mathrm{TC}_{37.98}\right)$, and "...responsibilities" $\left(\mathrm{TC}_{18,19}\right)$. On the other, the teacher candidates describe the gender equality as follows, "equal opportunities", “equal rights" $\left(\mathrm{TC}_{29,77,91}\right)$, “... no gender is superior to other and the individual shall be accepted as s/he is and s/he should never be discriminated in the society because of gender from birth or if the people change their gender later..." And they emphasized that "there should be no discrimination between girl and boy and very few teacher candidates mentioned "laws" and "equal participation in management (governance)". Apart from this, eight teacher candidates also referred to the LGBT and stated that sexual 
orientation should not be a reason for discrimination.

Teacher candidates have frequently related situations that produce inequality between the sexes with the processes of socialization and social role distribution between the individuals (Table 2).

Table 2. The situations where there is a gender inequality

\begin{tabular}{|c|c|c|c|c|}
\hline $\mathrm{F}$ & Theme & $\mathrm{f}$ & $\%$ & Sample sentence(s) \\
\hline \multirow{4}{*}{ 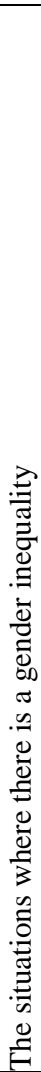 } & $\begin{array}{l}\text { को } \\
\frac{0}{0} \\
0\end{array}$ & 35 & 29,4 & $\begin{array}{l}\text { The biggest difference between men and women is that women can give birth. The } \\
\text { woman is naive and vulnerable while the man is strong }\left(\mathrm{TC}_{11}\right) \text {. Biological gender of } \\
\text { individuals is defined in the womb ... it is correct that men and women are not } \\
\text { physically equal. While the men have a more powerful, stronger body structure, the } \\
\text { women are more fragile... }\left(\mathrm{TC}_{12}\right) \text {. The leading circumstance that causes the gender } \\
\text { inequality is the biological structure of men and women. While a woman can give } \\
\text { birth and breastfeed, a man can't. Although the muscle structures of men are more } \\
\text { developed... }\left(\mathrm{TC}_{117}\right) \text {. }\end{array}$ \\
\hline & 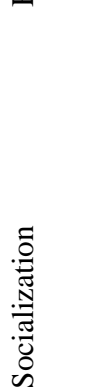 & 77 & 64,7 & $\begin{array}{l}\text {...one of the situations creating the inequality is the behavior taught to children by the } \\
\text { family members For example, when a boy cries, people tell, "Do the boys cry? They } \\
\text { don't", while a girl starts to speak to the family, the family tell her, "Don't say like } \\
\text { that, shut up". That's why people cannot act freely in the society. ( } \mathrm{TC}_{58} \text { ) In fact, } \\
\text { gender inequality is affected by the social factors. In the mother's womb, people buy } \\
\text { pink dresses for girls while they buy shorts for men, t-shirts, on which there are } \\
\text { heroes. When the baby is born, we give a girl a baby while we give a boy a plane and } \\
\text { this affects how we choose our profession. }\left(\mathrm{TC}_{119}\right) \text { Some mothers tell their son, "my } \\
\text { strong boy"... So the men think they are capable to do anything and they are the most } \\
\text { important thing in the world. They are spoiled and act without empathy. On the other } \\
\text { hand, girls are thought to be ashamed. }\left(\mathrm{TC}_{57}\right)\end{array}$ \\
\hline & $\frac{0}{2}$ & 70 & 58,8 & $\begin{array}{l}\text { They even choose the professions suitable for men and women. Since the women are } \\
\text { weak and powerless, people think that the women cannot be civil engineers. This is } \\
\text { also valid for men. For example, when we think about a nurse, we always think about } \\
\text { a woman. Because we don't expect the men to be a nurse. This is the simple logic. } \\
\left(\mathrm{TC}_{48}\right)\end{array}$ \\
\hline & 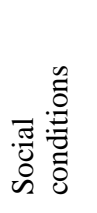 & 3 & 2,5 & $\begin{array}{l}\text { The great majority of the society discriminates between men and women as always. } \\
\text { Women are oppressed in comparison with men. Women are raised to be beaten, } \\
\text { deprived of work, despised, raped, incapable to dress, speak and they are not allowed } \\
\text { to leave the house and they are raised to be dependent on the husband. The reasons } \\
\text { behind the men's behaviors under the social pressure, family attitudes when the child } \\
\text { is raised, psychological disorders, alcohol, and honor. }\left(\mathrm{TC}_{73} \text { ) }\right.\end{array}$ \\
\hline
\end{tabular}

According to the teacher candidates, the differentiation starts from the initial interactions of the individual in the family, exceeds throughout the socialization process, and the families behaving differently to the boys and girls. When a boy cries, the family tells, "...Do the boys cry? They don't", while a girl starts to speak to the family, the family tell her, "Don't say like that, shut up ..." ( $\left.\mathrm{TC}_{58}\right)$, and how the behaviors are thought to them; "and say always their sons, "my strong boy..". "...so the boys think they are capable to do anything and they are the most important thing in the world." $\left(\mathrm{TC}_{57}\right)$, state teacher candidates.

According to teacher candidates, religious beliefs and prejudices are the most significant factors that produce the gender inequality (Table 3). 
Table 3. Factors that cause the inequality

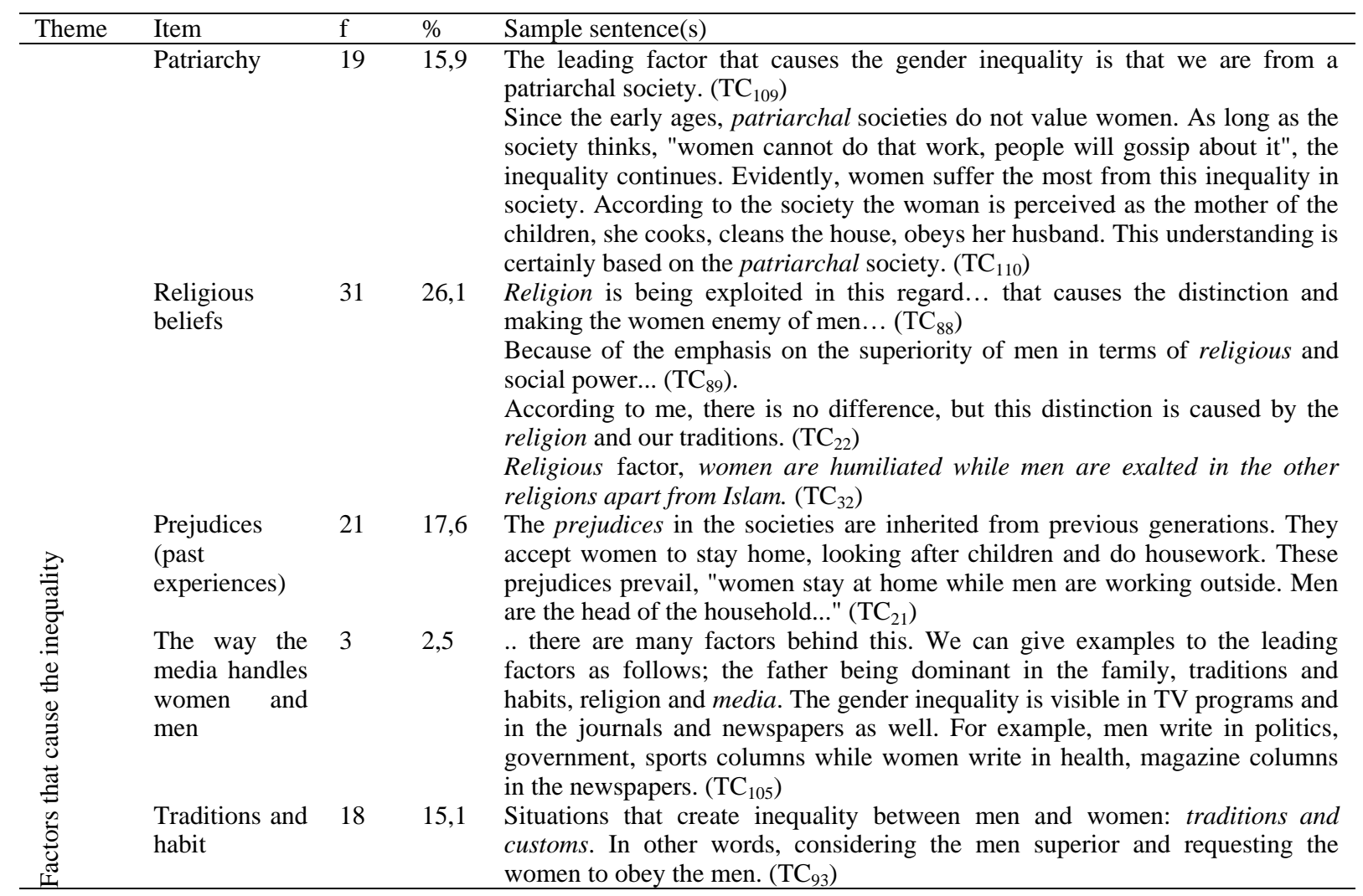

Teacher candidates consider the religious beliefs in two different ways: according to one opinion, the religion causes the inequality because "it considers the men superior in terms of religion and social power..." ( $\left.\mathrm{TC}_{89}\right)$. In other words, religion makes man superior. According to another view, the laws of religion are manipulated and religion is "exploited" in this respect $\left(\mathrm{TC}_{88}\right)$.

According to the classroom teacher candidates, people should be educated to ensure the gender equality (Table 4). 
Table 4. What can be done to ensure the gender equality

\begin{tabular}{|c|c|c|c|c|}
\hline Theme & Item & $\mathrm{f}$ & $\%$ & Sample sentence(s) \\
\hline & Personal & 46 & 38,7 & $\begin{array}{l}\text { Education, education, education! I am from the east side of Turkey. I realized that when } \\
\text { women are not educated, they had difficulties to express themselves. Although they were } \\
\text { beaten by their husbands, they couldn't object. If the women were educated, that wouldn't } \\
\text { be the case. People say the divorce rate is increasing in our country. In fact, I am happy } \\
\text { about this. According to me, women win their freedom. }\left(\mathrm{TC}_{39}\right)\end{array}$ \\
\hline & Family & 21 & 17,6 & $\begin{array}{l}\text { Nobody in this world is superior to anyone. Of course, our five fingers are not the same. } \\
\text { But when you bleed any of them, you would feel the same pain. I think the equality starts } \\
\text { from the family first. Because the child is raised in a family, if we can manage to give } \\
\text { him the right information, it means that we have taken the first step for making this child } \\
\text { an individual. }\left(\mathrm{TC}_{86}\right)\end{array}$ \\
\hline & Teacher & 6 & 5,0 & $\begin{array}{l}\text { The games in preschool education are arranged according to the sexist approach. During } \\
\text { the game times, the girls are directed to play house, while the boys are directed to play } \\
\text { with cars. In order to correct this from the beginning, the mentality of the teacher should } \\
\text { be improved and the teachers should be trained. }\left(\mathrm{TC}_{8}\right)\end{array}$ \\
\hline & Society & 30 & 25,2 & $\begin{array}{l}\text { Conferences should be organized in public education centers, for educating the } \\
\text { community... }\left(\mathrm{TC}_{45}\right)\end{array}$ \\
\hline \multirow{6}{*}{ 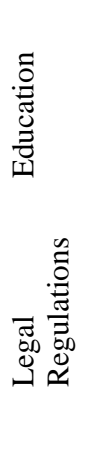 } & & & & $\begin{array}{l}\text { Society should be educated. It is necessary to distribute the brochures. Conferences on } \\
\text { women's health should be held. We must teach the society that violence against women is } \\
\text { wrong. }\left(\mathrm{TC}_{59}\right)\end{array}$ \\
\hline & $\begin{array}{l}\text { Deciding on the } \\
\text { training content }\end{array}$ & 38 & 31,9 & $\begin{array}{l}\text { The words in the textbooks that cause the gender inequality in the magazines should be } \\
\text { edited and removed from the curriculum }\left(\mathrm{TC}_{3}\right)\end{array}$ \\
\hline & & 21 & 17,6 & $\begin{array}{l}\text { We should consider the people as individuals rather than men and women. Women are } \\
\text { always left behind because there is no such equality today. We should make laws in this } \\
\text { regard. }\left(\mathrm{TC}_{49}\right)\end{array}$ \\
\hline & & & & Protecting the legal rights of LGTB individuals and integrate them into the society $\left(\mathrm{TC}_{29}\right)$ \\
\hline & & & & $\begin{array}{l}\text { There should be laws to ensure the equality between women and men, and those who do } \\
\text { not comply should be punished according to law. }\left(\mathrm{TC}_{34}\right)\end{array}$ \\
\hline & & 89 & 74,8 & $\begin{array}{l}\text { The family should be educated for ensuring the gender equality. Parents should not } \\
\text { discriminate between boys and girls. }\left(\mathrm{TC}_{79}\right)\end{array}$ \\
\hline \multirow{5}{*}{ 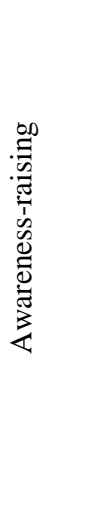 } & & & & $\begin{array}{l}\text { We can create games such as "Why not" or "Example street" at school events, and we } \\
\text { can get out of traditional gender stereotypes imposed on ourselves from early ages. } \\
\left(\mathrm{TC}_{80}\right)\end{array}$ \\
\hline & & & & We should raise the awareness of the people, and media should support us. $\left(\mathrm{TC}_{3}\right)$ \\
\hline & & & & $\begin{array}{l}\text { We should give up on representing the women as fragile, unintelligent and use them as } \\
\text { the sex object. Similarly, we should stop representing the men as powerful, strong and } \\
\text { people who do not get affected by anything. }\left(\mathrm{TC}_{29}\right)\end{array}$ \\
\hline & & & & $\begin{array}{l}\text { First of all, I think that the "Gender Equality" course should be given in the primary and } \\
\text { secondary education institutions in order to raise awareness of the future society on this } \\
\text { issue. Thus, we may contribute to creating a more conscious society structure. }\left(\mathrm{TC}_{34}\right)\end{array}$ \\
\hline & $\begin{array}{l}\text { Redistribution of } \\
\text { roles in the family }\end{array}$ & 46 & 38,7 & $\begin{array}{l}\text { In the family, while the woman may buy the groceries and men may prepare the food and } \\
\text { set the table. We shouldn't be forced to iron, prepare food, clean just because we are } \\
\text { female. And men shouldn't only drive, carry the bags and pay the bills just because they } \\
\text { are men. First, we have to take our blinders off and forget the prejudices and taboos, in } \\
\text { which we are trapped. }\left(\mathrm{TC}_{60}\right)\end{array}$ \\
\hline \multirow{2}{*}{ 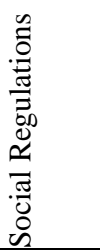 } & & & & $\begin{array}{l}\ldots \text { to treat equally girls and boys in the family, to decide with men when we want to have } \\
\text { children... }\left(\mathrm{TC}_{88}\right)\end{array}$ \\
\hline & $\begin{array}{l}\text { Promoting } \\
\text { women's } \\
\text { employment }\end{array}$ & 40 & 33,6 & $\begin{array}{l}\text { Women should be encouraged to take part in the professional life and employment should } \\
\text { be provided. }\left(\mathrm{TC}_{95}\right) \\
\text {...hence, we need to remove any obstacles in front of the women in business life, in } \\
\text { public space, in marriage. }\left(\mathrm{TC}_{116}\right)\end{array}$ \\
\hline
\end{tabular}

"Parents should not discriminate between boys and girls." in the family $\left(\mathrm{TC}_{79}\right)$ and "We can create games such as "Why not" or "Example street" at school events, and we can get out of traditional gender stereotypes imposed on ourselves from early ages." $\left(\mathrm{TC}_{80}\right)$, "the Gender Equality course should be given in the primary and secondary education institutions..." $\left(\mathrm{TC}_{34}\right)$ the above-mentioned points should be thought in the family; media should be controlled and the stereotypes should be eliminated: "...We should give up on representing the women as fragile, unintelligent and use them as the sex object. Similarly, we should stop representing the men as powerful, strong and people who do not get affected by anything.." $\left(\mathrm{TC}_{29}\right)$

\subsection{Data Obtained in the Focus Group Discussion}

Eleven questions were asked to the participants in the focus group discussion with the participation of nine participants, one moderator, one camera operator and one observer. Since the participants give their permission to use their names, presented their answers with their names, gender (female $=\mathrm{F}$, male $=\mathrm{M}$ ) and their age $(\mathrm{A})$. 
a. Why did you choose this department for studying? Does your gender play a role in your selection, if it does, how?

It has been understood that all of the students $(\mathrm{N}=9)$ are placed according to the results of the university exam. "So the examination has no effect on the gender...every person can study whatever s/he wants."(Barış, M, A:23).

It is understood that the teacher candidates were criticized about the selection of the department: "For example, there is a department for kindergarten education for being a teacher in the preschools. I mean, I have a friend, who is studying in this department and this is a man. A bodied man! People still ask him, "How do you study in this department?" A man or a rough-looking person can be a kindergarten teacher. In the end, the gender shouldn't be important. "(Barış, M, A: 23).

It is understood that students are directed according to their gender when selecting the departments and are not supported if they choose something considered as inappropriate: "I wanted to be a physical education teacher. People said to me, that it is not suitable for a woman! but when you choose to study in the classroom teacher department, people said it is a perfect job for women and it would be very good for raising your own child. It's not that I did not come willingly. "(Aynur, F, A: 19).

\section{$b$. What is the reason why the majority studying in education faculties is women?}

It is understood that the family of the students influenced the selection of the students and the woman is considered as responsible for the child's education and that's why the number of female teachers increased: "My master, in the end, you cannot make this selection alone. You are with your family... I mean, if you are a woman, the family doesn't want to choose engineering departments. The families prefer more comfortable and easier departments." (Ridvan, M, A: 24). "... schools seem more like a family environment ... people tend to think in the society: the mother educates the child ... because more women seem to be more related with this.." (Adalet, F, A:20), “...because it does not require physical power.." (Safiye, F, A: 21).

The second reason is that schools provide a safe working environment for women:“... "Because the women need more protection. I mean they feel this way. they would like to work in a more comfortable environment...(Maide, F, A:19).

c. Do you want to have more girls or boys in your class, why?

All of the students $(\mathrm{N}=9)$ reported that there was an equal number of male and female students in their class. Some students find even repulsive if the class consists of only girls or particularly only boys: "My master, you came to our class now. Other than me there are only two boys in the class... Only two! I don't know. It is repulsive..." (Ridvan, M, A: 24).

\section{d. What are the differences between girls and boys' in terms of learning?}

Those who participated in the study explained the difference of learning between boys and girls with the intelligence of the boys and the diligence of the girls; it is understood that some people define intelligence with the capacity: "... girls do achieve by working hard on it, but I think that men are generally intelligent and they can do it since they intelligent"...; "... but if girls want to achieve something, they struggle and work for achieving the objective. Nowadays, the majority of students consist of girls. I mean, they are very willing to learn. It is the case in terms of the profession as well." (Esra, F, A: 19). "Learning stages are not that easy ... men do not understand the direct result. They need to work hard... there are some men who are capable to do it within minutes! While there are some girls catching immediately the point, and there are some girls, who need to work for the whole semester... I think this is not about gender. People achieve since they work hard or they have the God's gift." (Barış, M, A: 23).

e. What influences the learning process of male and female students? Why is education prominent for girls and boys?

It is ascertained that the female students participating in the study pay attention to the role of education in providing a job as well as a social status. According to the participants, education is a prerequisite for employability for women. "... they say to the daughters, you have to study! but boys are more comfortable ... more free on this issue ... girls feel they have to study harder, I think they are trying harder because of this." Moderator: "Why do girls have to study?" “... will you be dependent on your husband? You have to work, you have to study! ... " (Adalet, F, A: 20).

According to the experience of the students, not every job may be suitable for a woman. "In a way, it is because there is a trend in Turkey, my master: For example, there is a limitation for women ... it seems there is as far as I observed. A woman can not work in every area! " (Ridvan, M, A: 24).

Again according to the participants, the tasks that require muscle strength are more suitable for men, while the jobs requiring more analysis and understanding are suitable for women. It is not possible for women to work in every professional environment. In order for women to work, their physical and mental security must be ensured: "I don't know my Master. For example, you can not see observe a woman at a construction site or at an industrial site. But in 
general, in more elegant professions... for example a teacher... teachers are generally women in Turkey... As my friends told so, being a classroom teacher is considered as a more suitable job for women... Hence, the women need to attach more importance to the education." (Ridvan, M, A: 24).

\section{f. In which learning fields are male and female students more successful? How does being a man/woman make it successful on the field?}

It is noted that students think that male students are more likely to be interested to work with numbers while more verbal areas are considered more appropriate for women: For men: "... engineering. There is a phenomenon in Turkey: people ask why men choose a verbal department... It seems that it is more popular for men to work with numbers. They think men should work with numbers... It seems they are more prone to work with numbers. (Ridvan, M, A: 24).

According to the participants, men are more successful in jobs, where they can produce a concrete product:"... men are thinking concretely. They are more successful in concrete jobs in comparison with women... women cannot succeed in the mechanical work, but the men are better at this. The men are more successful for creating concrete things... these are more material areas... On the other hand, women are more successful in abstract thinking, they may generate new ideas. It seems the women are deficient in creating something." (Aynur, F, A: 19).

\section{g. Do you think female or male students will cooperate more with you in the management of the class?}

According to the gender of the teacher candidates, the teacher candidates noted they would receive more help from the students from the same gender in classroom management, and stated that it wouldn't be suitable with morality and culture otherwise: "... men are a bit closer to men, compared to the ladies. You cannot hit it off with a woman, particularly in Turkey...since the line cannot be crossed... people say, how can you be a friend with a woman... That's why men hit it off with men, while women hit it off with women..." (Ridvan, M, A: 24). "... when we were young, we experienced what master Ridvan told. The teacher was a woman and she was more interested working with the girls. We were just hanging around in the back seats...On the other hand, we had a male teacher, he always interested in us." (Barış, M, A: 23). "... girl students actually hit it off better with male teachers ... and there is something like this ... female teachers are rougher... at least the female teachers that I have met were so. I think it would be better if the teacher was a lady until the fifth grade of primary school" (Maide, F, A: 19). Moderator: But you said they were rougher? "Because they have the feelings of motherhood and they are finer...after the fifth grade, the teacher should be a male..."(Maide, F, A: 19).

h. While you were studying, the leaders were male or female in your class? Which qualities of girls/boys made them lead the class?

Classroom candidates reported that both girls and boys displayed leadership qualities in their class. The leadership of men is based on their muscle strength: "the girls were leaders?... they were strongly built I suppose! (laughs in the whole group) ... girls were never influential in our class..." (Barış, M, A: 23). Moderator: the leader should be muscular? "...it is not about the muscles... We were the majority. That's why the girls should follow whatever we do... We played with 4 balls and gave the girls one ball. They were playing with one ball. That's how we were at that time." (Barış, M, A: 23). According to participants, physical strength gives the right to lead other people, and this is also used by teachers to control the class: "My Master, that's what I call a "strategic decision". I mean, for example, beat everyone in my classroom... And the teacher selected me as the class president... Nobody could object... That's for the primary school of course... The teacher said, "You will be the president"... Nobody even voted for it. Even if the teacher put it to the vote, I would receive all the votes. I put such a pressure on the students... All the boys should give me the vote... Otherwise, I would beat them." (Barış, M, A: 23).

In situations where the women lead, the reason is that they more closely analyze the events or the job: "...Obviously, the boys were leading but there was a thing about the girls. The girls were very successful in the management. For example, we had a girl in our class. She was the President. When you go somewhere; for example, for a picnic. The girls were leading... Because they know better the details..."(Ridvan, M, A: 24).

Another participant, on the other hand, seems to consider strange that girls are nominating themselves for becoming president and they become president: "Our majority consisted of men. However, I don't know why but the president was always a girl... The presidents of the class were always girls, not a boy once..." (Ahmet, M, A: 20).

Another student emphasizes that the fields where girls dominate are provided and protected by men: "... girls were leaders in general in our class, while boys were usually misbehaving. Girls were leading in the classroom ... we were usually able to play together. If we were going to play the match we were playing together. The men were leading the match. They would keep the girls a bit behind. Oh, so that girls do not get hurt because of the ball!" (Adalet, F, A: 20). "Football is a bit rough sport. Now if I fight with a girl, shoulder to shoulder... She would stay in bed for three days... Or I shot a ball, a girl may be hurt (looking at girls)...(pointing out the girls) there are girls playing soccer. Do not get me 
wrong... Football is really a rough sport... This is not something like volleyball..." (Barış, M, A: 23). "...some human conditions prevail... the gender matters in the sports..."(Rıdvan, M, A:24).

Another student thinks that girls dominate some areas since the girls constitute the majority, or they persuade people by talking, their social capabilities and their senses of responsibilities: "... how they achieve this? ...With the communication in the class, with the entourage, with solidarity and sensitivity... With charitableness... the girls are generally good."(Aynur, F, A: 19).

\section{i.Female teachers or male teachers were more successful in managing the class?}

According to the participants, the success in classroom management is related to attitude, not to gender, of the teachers: "... I think this is something about the attitude of the teacher, rather than his/her gender. For example, there are some teachers. In university, they are so gentle. When s/he explains something, we can comment... The teacher doesn't get mad and say, "why do you comment while I am explaining something?" But there are some teachers, acting severely. If you want to comment, you need to raise your hand." (Ridvan, M, A: 24).

\section{j. Which gender is more constructive or solution-oriented in solving problems that are created in the class?}

It is noted that the participants do not relate the problem-solving capability with the gender, they consider this as a matter of character, and they partially consider the women as successful: "this is not about the gender. It depends on the character... It is about the event as well." (Esra, F, A: 19). "... I don't know about this issue but... I think the girls are more solution-oriented." (Ahmet, M, A: 20).

It was explained that while the participants were solving their problems during their own learning period in their classrooms, male teachers were trying to eliminate the problem and female teachers were trying to find a reconciliation: ...for example, if a child had a problem with the teacher. The school administration (Administrators are men) tends to say, "let's expel the student and the problem will be solved". So that there will be no harm for the teacher and the student! On the other hand, the female teacher strives to find why the child behaved likes this... And she said, let's find the solution to the problem and let's reconcile. (Adalet, F, A: 20).

It is ascertained that when male teachers are approaching particularly the female students' problems in a sexist way and they blame them for not complying with the norms and values of the society: "... our girlfriend was constantly escaping from the school ... our Assistant Principal was a conservative teacher ... S/he called the girl's family and said something. Six boys in class have escaped and that girl has escaped independently from them. S/he called the girl's mother and said, "your daughter escaped from school with six guys" (laughs). She just came to the school. Our class teacher was a woman. She said to her mother, "These things happen. Your daughter is determined. Let's fight together". The Assistant Principal just said, "This is not going to happen. Take your girl out of the school..." (Adalet, F, A: 20).

$k$. What were the characteristics of the female and male teacher that matter in the successful management of the classroom?

According to the participants, the success in classroom management is related to the character of the teacher who leads the class. While female teachers succeed to manage the classroom by the authoritarian attitudes, detailed thinking and detailing, the success of male teachers depends on their comfortable attitudes: "... I do not think it has anything to do with gender. But there are some female teachers, who are very authoritarian in class. But we had some male teachers that are very comfortable in the class. This is about the person's character .. some of them are careless...some of them think all the details. (pointing out Meryem) My friend thinks every detail. I am not like this. This is not about gender. (Safiye, F, A: 21).

According to the participants, teachers are expected to use problem-solving skills for a good classroom management. The success of a student is influenced by the organization of the teacher in the class. Female teachers contribute to the success of their students with their detailed attitudes and problem-solving skills: "there is something like this. This is about the education of the child while s/he was very little... about the things s/he learn from the teachers and what s/he observes in the class...received a good training...if the child encounters a good classroom teacher, the child succeeds. Whether it is a girl or a boy...I think the girls are more attentive to the details, but the boys are not very talented in problem-solving, but... " (Maide, F, A: 19).

The students, who participated in the focus group discussion, have the same experience about the school management: Moderator: were your Principal men or women?

Group: Male!

Adalet (F, A: 20) and Aynur (F, A: 19): "We never had female principals". ; Ridvan (M, A:24): Same for me.

Moderator: What do you say about this: Teaching is a field dominated by women. Women perform this job. But when it comes to the administration, men mostly do this job, why so? 
It was ascertained that the participants explain the male domination in the school administration by the patriarchal social structure and the fact that the high management of the system is generally ensured by the men. They also emphasize that the women were allowed by men to manage an area: "My master, we are a patriarchal society. We are giving you this profession but! Let me warn you we are in charge! We manage it! I think this is like this." (Adalet, F, A: 20).

\section{Discussion and Conclusion}

Public education is the most powerful legitimate way for the society to transfer its value judgments, thoughts, lifestyle practices, legal rules, ideologies to its new generation; hence, it ensures the continuity of cultures generated until that day. Throughout this education, some information conveyed to the new generation is not explicitly stated in the curriculum. The roles expected from the boys and girls, who will form the new society, are first shared in the families, then in the schools when the children are old enough. Thus, the defined roles of men and women continue.

According to the results of this research, the students, who participated in the research described the gender equality in relation to the "female" and "male" gender, and frequently used following terms: the "equal rights", "equal value", "being one", " equal treatment "," equal access to all kinds of rights "and" equalization of rights and responsibilities ". Participants ascertained that the factors that create inequality by emphasizing the psychological processes of men and emotional processes of women, such as "being physically stronger", "being fragile", "being elegant", "being emotional". According to the classroom teacher candidates, the inequality is the result of "distribution of roles in the family", "patriarchal social order", "prejudices", "biological and physiological differences", "manipulation of religious beliefs", "society customs and traditions" and "experiences" and finally "the style how the media represent the men and women".

Classroom teacher candidates perceive women more passively while the men more actively during their learning period. According to the participants, biological gender has no role in career selection. Having a profession and getting this profession with a good education is essential for a woman, for not being dependent on a person (a man) in life. Women are better suited to work in fields where they can comfortably fulfill their motherhood responsibilities. Classroom teacher candidates are experiencing that the men selecting the professions that are considered more suitable for the women are regarded as strange like the women selecting the professions that are considered more suitable for the men. For example, being a pre-school teacher may not be suitable for "a bodied man". It may not be appropriate for women to operate in every business field since their physical and mental security cannot be guaranteed or it is challenging to do so. For example, it is not appropriate for women to work with other men in the industrial site. Other men working in this area may be a threat in terms of emotional and physical violence for women. Nevertheless, classroom teacher candidates find the workplaces, where there are exclusively men or women; even they consider this as "repulsive". According to them, the number of men and women in the workplace should be balanced. However, they need to socialize in this field; they prefer to socialize with their own gender. This is because the classroom teacher candidates have observed that male students interact with male teachers in the classroom while female students can communicate better with female teachers. They also predict that they will communicate more easily with their gender in their class, as well. Otherwise, it may contradict the moral limits of the society. It can create adverse events. Although this perspective was shared by a different study group, it is partly supported by the research results of Lee, Smith and Cioci (1993). Researchers discovered those teachers' perceptions of their own power at school in terms of personal, interpersonal, and organizational levels change according to the gender of the School Principal. The study revealed that female teachers felt more confident and powerful in personal, interpersonal and organizational when they are managed by a female Principal; on the other hand, the male teachers felt weaker in personal, interpersonal and organizational when they are managed by a Female Principal. This research suggests that the reason behind this is that the society has established certain standards for male and female relationships and that the relationship between teacher-student, master-student, student-student can be misunderstood and can be considered as an emotional or romantic relationship.

According to the student classroom teachers, men are more successful than women in the fields requiring to work with numbers. Women, on the other hand, are less successful to create concrete products according to the study. Women can think, talk, suggest ideas, but cannot produce concrete products. The research results of Miller and Chamberlin (2000) examining the opinions of the sociology students about the educational achievements of the faculty members are impressive in this context. The results of the research revealed that sociology students evaluated the educational achievements of female instructors (even they are really professors) at the "teaching" level while evaluated the educational achievements of male instructors at the "professorship" level. According to the study of Samuelsson \& Samuelsson (2016) on the difference in the perceptions of girls and boys about the teaching and learning of mathematics, men are more active in mathematics learning in comparison to the girls. In the classroom environment, male students believe that they can participate in group work more than female students and intervene the content of the lesson. Researchers explain this by the fact that the male students receive more frequent directives from teachers, as it is assumed that male students are more likely to behave in a way to disrupt the peace generally in the classroom. 
According to the research, in the same process, girl students arrange their own learning (self-regulation) rather than group work.

According to the student class teachers, the classes are male-dominated areas. Men have acquired this dominance with their physical strength. However, if a woman is leading a group or followed by others, this is because the woman is good, helpful, sensitive and friendly. Chemers (2000) proposes three theoretical explanations of the variations between male and female leaders: Biological Differences (hormones and temperament), Cultural Differences (circumstances brought by different social roles for different roles), Structurally Identified Differences (relative status according to organizational structure). However, practices reveal that there is very little difference in the leadership of the two genders (Eagly, Makhijani \& Klonsky, 1992). In other words, there is no significant difference between male and female leaders. However, the main difference between the women leaders is the attitude of people around the leader. Because of the prejudges, implying that the women have a limited leadership capability or that are emotionally unstable, the women are considered as inappropriate management candidates (Crawford, 2001). In fact, classroom teacher candidates also define successful female teachers in the class as authoritarian and rough. Women, on the other hand, are organized and elaborative. When solving the issues, women strive for reconciliation while men try to avoid the problems. Although the management of the entire process is considered as an area dominated by men.

Although we do not know how a healthy distribution of role would be achieved between men and women in the community, the results of this research reveal that at least both genders are in an effort to create fields that are appropriate for each other's physical and emotional competencies. Since classroom teacher students are aware of the differences between the genders and the problematic areas, we may think that there might be positive developments in the distribution of roles between these two genders thanks to the education. Actually, Vatandaş's (2007) research exposes that, despite all the negativities, as the level of education increases, the negativities on gender weakens considerably.

\section{Acknowledgements}

The descriptive analysis of this research was presented as a verbal statement during 15th International Primary Teacher Education Symposium, held between 11-14 May 2016 at Sttkı Koçman University, Muğla, Turkey while the data obtained by the focus group discussion was presented as a verbal statement during the 8th International Education Management Forum, held between 19-21 October 2017, at Ankara TOBB ETÜ and the abstracts are included in the abstracts of the statements.

\section{References}

Akbaba-Altun, S., \& Apaydın, Ç. (2013). Kız ve erkek öğretmen adaylarının "eğitim" kavramına ilişkin metaforik algıları. [Metaphorical perceptions of female and male teacher candidates regarding the concept of "education"]. Kuram ve Uygulamada Eğitim Yönetimi [Educational Administration: Theory and Practice], 19(3), 329-354.

American Psycological Association. (2011). Guidelines for psychological practice with lesbian, gay, and bisexual clients. Retrieved 18 May, 2017 from http://www.apa.org/pubs/journals/features/amp-a0024659.pdf

Aslan, G. (2015). Öğretmen adaylarının toplumsal cinsiyet algılarına ilişkin metaforik bir çözümleme [Metaphorical analysis of teacher candidates' gender perceptions]. Eğitim ve Bilim [Education and Science], 40(181), 363-384.

Aydemir, P. Y. (2013). Antropolojide sınıf ve toplumsal cinsiyet gerilim hattında Marksist ve feminist yaklaşımlar [Marxist and feminist approaches to anthropological class and gender tension]. Insanbilim Dergisi [Anthropology Journal], 1(2), 108-120.

Bigler, R., Hayes, A. R., \& Hamilton, V. (2013). The role of schools in the early socialization of gender differences. Encyclopedia on Early Childhood Development. Retrieved May 18, 2017 from http://www.child-encyclopedia.com/gender-early-socialization/according-experts/role-schools-early-socialization-g ender-differences

Brickell, C. (2006). The sociological construction of gender and sexuality. The Sociological Review, 54(1), 87-113.

Brown, H. (2014). Marx on gender and the family: A summary. Monthly Review, 66(2). Retrieved November 29, 2017 from https://monthlyreview.org/2014/06/01/marx-on-gender-and-the-family-a-summary/

Buell, M. J., Hallam, R., Gamel-Mccormick, M., \& Scheer, S. (1999). A survey of general and special education teachers' perceptions and inservice needs concerning inclusion. International Journal of Disability, Development and Education, 46(2), 143-156.

Caldarella, P., Shatzer R. H., Richardson, M. J., Shen, J., Zhang, N., \& Zhang, C. (2009). The impact of gender on Chinese elementary school teachers' perceptions of student behavior problems. New Horizons in Education, 57(2), 17-31. 
Carignan, N., Sanders, M., \& Pourdavood, R. G. (2005). Racism and ethnocentrism: Social representations of preservice teachers in the context of multi- and intercultural education. International Journal of Qualitative Methods, 4(3), $1-19$.

Chapman, A. (2002). Gender biases in education. Retrieved November 29, 2016 from http://www.edchange.org/multicultural/papers/genderbias.html

Chronaki, A. (2012). Disrupting 'Development' as the Quality/Equity Discourse: Cyborgs and Subalterns in School Technoscience. G. Katsiampoura \& A. Vogt (Ed.), In Gender studies and science (p. 11-29). Athens, Greece: Nissos.

Convention on the Elimination of All Forms of Discrimination against Women (CEDAW) (1981). Retrieved August 12, 2016 from http://www.ohchr.org/Documents/ProfessionalInterest/cedaw.pdf

Crawford, A. L. (2001). Woman in leadership: stereotyping of woman. Kellogg Journal of Organizational Behavior. $\begin{array}{llll}\text { Retrieved } & \text { May } & 20, & 2017\end{array}$ https://www.kellogg.northwestern.edu/research/ktag/resources/papers/crawford.pdf

Çoban, A. (2005). Örgüt kültürü ve toplumsal cinsiyet analizi: Bankacılık sektöründe bir araştırma. Yayınlanmamış Yüksek Lisans Tezi. Ankara: Ankara Üniversitesi Sosyal Bilimler Enstitüsü İşletme Anabilim Dalı [Organizational culture and gender analysis: A research in the banking sector. Unpublished Master's Thesis. Ankara: Ankara University Social Sciences Institute Business Administration Department.].

Çokluk, Ö., Yılmaz, K., \& Oğuz, E. (2011). Nitel bir görüşme yöntemi: Odak grup görüşmesi [A qualitative interview method: Focus group discussion.]. Kuramsal Eğitimbilim [Theoretical Education], 4(1), 95-107.

Dawson, C. (2009). Introduction to research methods: A practical guide for anyone undertaking a research project. Oxford: How to Books.

Duffy, J., Warren, K., \& Walsh, W. (2001). Classroom interactions: gender of teacher, gender of student, and classroom subject. Sex Roles, 45, 579-593. https://doi.org/10.1023/A:1014892408105

Eagly, A. H., Makhijani, M. G., \& Klonsky, B. G. (1992). Gender and the evaluation of leaders: A meta-analysis. Psychological Bulletin, 111, 3-22. http://doi.org/10.1037/0033-2909.111.1.3

Gender. In Merriam-Webster online dictionary. Retrieved April 11, 2016 from https://www.merriam-webster.com/dictionary/gender

Gender. In World Health Organization. Retrieved April 09, 2018 from http://www.who.int/gender-equity-rights/understanding/gender-definition/en/

Hofstede, G. (1986). Cultural differences in teaching and learning. International Journal of Intercultural Relations 10(3), 301-320. https://doi.org/10.1016/0147-1767(86)90015-5

Istanbul Psychiatric Institute. Cinsel yönelim [Sexual orientation]. Retrieved April 11, 2016 from http://www.ipe.com.tr/tr/icerik/71/cinsel-yonelim

Kleinfeld, J. (1998). The myth that schools shortchange girls: Social science in the service of deception. Washington D.C.: Women's Freedom Network.

Kokkinos, C. M., Panayiotou, G., \& Davazoglou, A. M. (2004). Perceived seriousness of pupils' undesirable behaviours: The student teachers' perspective. Educational Psychology, 24, 109-120.

Lee, V. E., Smith, J. B., \& Cioci, M. (1993). Teachers and principals: gender-related perceptions of leadership and power in secondary schools. Educational Evaluation and Policy Analysis, 15(2), 153-180. http://doi/abs/10.3102/01623737015002153

Macionis, J. J. (2012). Sosyoloji. [Sociology] V. Akan (Translation Editor). Ankara: Nobel.

Mason, K. O. (1997). Gender and demographic change. What do we know? Jones, G. W., Douglas, R. M., Caldwell, J. C. and D'Souza, R., M. (eds). In The continuing demographic transition (pp: 158-182). Oxford: Clarendon.

Miller, J., \& Chamberlin, M. (2000). Women are teachers, men are professors: A study of student perception. Teaching Sociology, 28(4), 283-298. Doi: 10.2307/1318580

Mooij, D. M., \& Hofstede, G. (2010). The Hofstede Model: Applications to global branding and advertising strategy and research. International Journal of Advertising, 29(1), 85-110. http://doi.org/10.2501/S026504870920104X

Neuendorf, K. A. (2002). The content analysis guidebook. Thousand Oaks, CA: Sage.

Özen, F. (2015). Evaluation of the attitudes of teacher candidates towards democracy and multicultural education. 
International Journal of Humanities and Education, 1(2), 182-220. Retrieved 08 March, 2017 from http://www.ijhe.org/Published/201510_002_1_004.pdf

Qualified Teacher Training Congress. (2017, 30 November). Hürriyet Gazetesi [Hürriyet Newspaper]. Retrieved 18 March, 2018 from http://www.hurriyet.com.tr/nitelikli-ogretmen-yetistirme-kongresi-40663291

Reid, M. E. (2008). A feminist sociological imagination? Reading Ann Oakley. Sociology of Health\&Illness, 5(1), 83-94. http://doi.org/10.1111/1467-9566.ep11340070

Sadker, D. (2002). An educator's primer to the gender war. Phi Delta Kappan, 84(3), 235-44. http://doi.org/10.1177/003172171109200523

Sadker, M., \& Sadker, D. (1994). Failing at fairness: How our schools cheat girls. New York: Touchstone.

Saltzman, A. (1994, November 6). "Myth or fact? Do teachers and schools favor boys to girls' detriment as some studies seem to show? Are single sex schools the only answer?" U.S. News and World Report, page. 4.

Samuelsson, M., \& Samuelsson, J. (2016). Gender differences in boys' and girls' perception of teaching and learning mathematics. Open Review of Educational Research, 3(1), 18-34.

Sayılan, F. (2012). Toplumsal cinsiyet ve yetişkin okuma yazma eğitimi: Ders kitaplarının eleştirel analizi [Gender and adult literacy education: Critical analysis of textbooks]. F. Sayılan (Gleaner.), In Toplumsal cinsiyet ve eğitim [Gender and education ] (pp. 77-102). Ankara: Dipnot.

Shepherd, L. J. (2008). Gender, violence and security: Discourse as practice. London: Zed.

Shepardson, D. P., \& Pizzini, E. L. (1992). Gender bias in female elementary teachers' perceptions of the scientific ability of students. Science Education, 76, 147-153. http://doi.org/10.1002/sce.3730760204

Sommers, C. H. (2000). The war against boys: How misguided feminism is harming our young men. New York: Simon and Schuster.

Tan, M., Ecevit Y., \& Üşür, S. S. (2000). Kadın-erkek eşitliğine doğru yürüyüşs: Eğitim, çalışma yaşamı ve siyaset [Walk towards equality between men and women: Education, working life and politics]. İstanbul: TÜSİAD.

Tanrı̈̈ver H. U., \& Danac1-Yüce, Ö. (2007). Symbolic annihilation of women in Turkish daily press. In Mass media research: International approaches (pp.183-192). Yorgo Pasadeos \& Dimitra Dimitrakopoulou (Ed.). Atiner, Athens, Greece.

United Nations (UN). (1948). Universal Declerations of Human Rights. Retrieved March 08, 2016 from http://www.un.org/en/universal-declaration-human-rights/

UNICEF \& UNESCO. (2013). The World We Want-Making Education a Priority in the Post-2015 Development Agenda: Report of the Global Thematic Consultation on Education in the Post-2015 Development Agenda. $\begin{array}{lllll}\text { Retrieved } & 09 & \text { April, } & 2017 & \text { from }\end{array}$ https://www.unicef.org/education/files/making_education_a_priority_in_the_post-2015_development_agenda.pdf

UNESCO. (2015). A guide for gender equality in teacher education policy and practices. Retrieved 10 June, 2017 from http://unesdoc.unesco.org/images/0023/002316/231646e.pdf

United Nations Human Rights Office. (1966/1976). International Convenant on Economic, Social and Cultural Rights. Retrieved 10 June, 2017 from http://www.ohchr.org/EN/ProfessionalInterest/Pages/CESCR.aspx

Vatandaş, C. (2007). Toplumsal cinsiyet ve cinsiyet rollerinin algılanışı [The perception of gender and gender roles]. Sosyoloji Konferanslart Dergisi (Istanbul Journal of Sociological Studies), 35, 29-56.

Yıldırım, A., \& Şimşek, H. (2005). Sosyal bilimlerde nitel araştırma yöntemleri [Qualitative research methods in the social sciences]. Ankara: Seçkin.

\section{Copyrights}

Copyright for this article is retained by the author(s), with first publication rights granted to the journal.

This is an open-access article distributed under the terms and conditions of the Creative Commons Attribution license which permits unrestricted use, distribution, and reproduction in any medium, provided the original work is properly cited. 